Journal of the Bangladesh Association of Young Researchers (JBAYR), Volume 1, Number 1, January 2011, Page 49-77

ISSN 1991-0746 (Print), ISSN 2220-119X (Online), DOI: 10.3329/jbayr.v1i1.6839

\section{BRIDGING DIGITAL DIVIDE THROUGH PUBLIC, SCHOOL AND COLLEGE LIBRARIES: A CASE STUDY OF BANGLADESH}

Nafiz Zaman Shuva and Rowshon Akter

Department of Information Science and Library Management, University of Dhaka, Dhaka-1000, Bangladesh.

E-mail: nafiz_z@hotmail.com, rowshondu@gmail.com

\begin{abstract}
The least developed and developing countries are combating against digital divide in order to keep the wheel of development rolling and escape from the vicious circle of poverty as digital divide is one of the key factors that can lead the poverty situation of these nations to an extreme level. In Bangladesh, the digital divide condition is severe. It is imperative for Bangladesh to take effective steps to bridge the digital divide and ensure ICT facilities at the national level. Recently as government pledged to convert Bangladesh into 'Digital Bangladesh' by 2021 which is the golden jubilee year of the independence of Bangladesh, several initiatives have been taken to overcome the digital divide and to produce future qualified generations. However, it has been observed that no worth mentioning project has yet been taken by any government that ensures proper development of the public, school and college libraries. Government should realize the fact that complete development of the country is never possible unless we concentrate library based education. It is not possible for any government to ensure the possibility to provide computer with internet connection to each and every family in Bangladesh, although, it may be possible to provide ICTs at school, college and public libraries. The authors of this paper firmly believe that ensuring ICTs to public, school and college libraries will greatly reduce digital divide at the national level and will produce qualified, efficient ICT competent future generations. An attempt has been made to show the existing digital divide in the country, current ICT scenario and core
\end{abstract}

projects that have been taken by government, NGOs, donor agencies and other development organizations. The inherent objective is to demonstrate how public, school and college libraries could reduce digital divide at the national level. It is believed that coordinated, long-term, effective projects/programmes to reduce digital divide will ensure peaceful, educated, qualified, ICT competent future generations.

KEYWORDS: Digital Divide, ICT Scenario Bangladesh, Government Initiatives, Non-government initiatives, Public libraries, School libraries, College libraries.

\section{INTRODUCTION}

Introduction, adoption and implementation of sophisticated affordable information and communication technologies (ICTs) are a common trend now in all the developed countries of the world. Since the invention of Internet in 1969 by ARPANET ${ }^{1}$ and WWW in 1990 by Tim Berners-Lee, the world has witnessed ceaseless development of ICTs. The intention of easy and quick processing of and access to information is responsible for this ICT revolution. Since present time is addressed as an information age, and nations worldwide are trying to establish knowledge based societies, instant access to right information is a prerequisite. In fact quick access to information has become key determinant of personal, national, regional and after all global development. Despite all the efforts of ICT development and usage, a major percentage of world's population especially of the least developed and developing countries is unable to avail ICTs to get access to latest information due to negligence, unawareness, ICT illiteracy, etc. In reality, the growth of new technologies has exacerbated the already extreme differences between the rich and the poor countries and between the poor and the rich; men and women in poorer countries'. This reveals that the technological revolution has put forward greater opportunities as well as challenges before nations. It has divided the world's population into two groups: people having access to ICTs and people without it. This division has been termed as digital divide (DD).

In 2001 UNESCO ${ }^{2}$ defined the digital divide as 'a phenomenon that results from the unequal application of, and access to, information and communication technologies leading to a global knowledge gap between information 'haves' and 'have-nots'. People having inclusive and speedy access to information through assigned ICTs, constitute the beneficiary 
group whereas people having limited or zero access to information are fallen in the distressed group who risk further marginalization in societies where ICT skills open the doors to: 'economic success and personal advancement, entry to good careers and educational opportunities, full access to social networks, and opportunities for civic engagement' ${ }^{3}$

Like other developing countries, Bangladesh (BD) (a country with a population of more than one hundred and sixty million) suffering badly from acute shortage of ICT facilities and skills at different categories of its population, organizations and so on (shown later in this article). The causes behind these divide are underdeveloped economy, low education rate, bureaucratic indifferent attitude etc. Though some initiatives have been taken at government and private sectors to minimize the digital gap, these are not enough to bridge the multidimensional digital gaps in Bangladesh.

\section{OBJECTIVES OF THE STUDY}

An understanding of prevailing digital divide situation of a country is very important that can help further improvement. This study is an attempt to build such kind of an understanding. The main purpose of this study is to show how public, school and college libraries can reduce digital divide at the national level. Other objectives are:

1. To state the existing digital divide scenario in Bangladesh.

2. To show the current ICT status in Bangladesh.

3. To explore the major initiatives taken by government in collaboration with donor countries/agencies, NGOs, private bodies etc. to bridge the digital gap.

4. To demonstrate the exiting status of ICTs in public, school and college libraries, and finally

5. To offer a proposal to bridge digital divide through public, school and college libraries.

\section{METHODOLOGY}

This study is qualitative and quantitative in nature. In order to maintain clear ideas on digital divide, its nature and impacts on societies, digital divide scenario of different countries, comprehensive literature search has been conducted by authors of this paper. Online databases subscribed by Oslo University College, Tallinn University and University of Dhaka have been consulted in order to find the relevant papers in this study. As one of the authors of this paper is currently a scholar of International Master in
Digital Learning, he has the privilege to access subscription based databases owned by his course universities. In addition an in-depth search has been conducted using Google. A very few literatures have been found that directly and comprehensively cover digital divide scenario in Bangladesh. In case of free journals the search output was filtered by Google scholar to have precise result. Two search techniques have been used: phrase search and Boolean search. Keywords and phrases used to conduct both the searches are: digital divide, impact of digital divide, bridging digital divide, role of libraries in bridging digital divide, digital divide scenario in India. Similar search statement has also been used for Africa and Malaysia. Later on, in order to retrieve information on the digital divide vista of Bangladesh and government's initiatives to bridge the divide, the search has been relaxed to all kinds of web resources. The search techniques remained the same. Keywords used for this section are KOICA, JAICA, UNDP, UNESCO, World Bank, Microsoft, Grameen Bank and BRAC. Each of these keywords has been combined by Boolean operator 'AND', with key words like Bangladesh, ICTs, projects, and initiatives. In addition to newspaper articles, different project proposals have been consulted extensively. Personal contacts have also been used to gather relevant information for this study.

\section{SCOPE OF THE WORK}

This study covers the following areas:

- major ICT infrastructure and access to ICTs in Bangladesh

- existing digital divide scenario in Bangladesh

- government, NGO, and other organizations' initiatives to upgrade peoples' skill to increase quality and quantity in ICT penetration for required information

- ICT infrastructure in public, school and college libraries

Based on these endeavours, a model proposal for reducing digital divide through public, school and college libraries has been put forward to combat digital divide in Bangladesh.

\section{LIMITATIONS}

The study is limited to comprehensive secondary sources of information that are available online through Oslo University College, Tallinn University and University of Dhaka subscription based online databases. A large 
number of printed documents available at different government and nongovernment offices were not possible to consult due to administrative juggleries and time constraints. This study should not thus be considered as the only comprehensive source for the topic. However, authors of this paper tried their best to make this paper as comprehensive and resourceful as possible.

\section{LITERATURE REVIEW}

Owing to the importance of ICTs in the development of every sphere of human life, several studies have been conducted globally to measure the digital divide situation between and within different communities. Mutula $^{4}$ in his keynote presentation at the $11^{\text {th }}$ DIS Annual conference addressed that the current approaches toward building digital divide free environment, especially in third world countries, have failed to harvest intended outcomes. He blamed that present initiatives are taken into action without integration of the socio-cultural and economic milieu of the people concerned. Instead of present actions he has given emphasis on the development of informatics to solve the problem.

In his study Kainth ${ }^{5}$ showed that digital divide between countries is usually measured in terms of the number of telephones, computers, access to Internet, etc. whereas within a country the divide is measured under the factors of race, gender, age, disability, location, income, etc. The main focus of his study is based on the reasons behind the complex rural divide and the obstacles to acquiring Internet access. He also has highlighted the initiatives taken by India to bridge the digital gap of rural people.

In a study $\operatorname{Singh}^{6}$ made an attempt to evaluate the efforts made in India to bridge the digital divide. The author tried to examine major programmes/projects undertaken by government, non-government organizations, and private business houses and simultaneously discussed the challenges and barriers to digitization. In this study emphasis has been laid to strong determination, good policy making and political support as core remedial measures to overcome the DD situation in India.

Oliver ${ }^{7}$ examined the nature of an Internet Pilot's Training Programme, conducted in 2000-2001 by Saskatchewan's public libraries. The training programme was designed for Saskatchewan rural people who did not have Internet access or ICT skills to make qualified use of digital resources. The training programme intended to information literacy augmentation with
ICT skill development of Saskatchewan rural people. Oliver's research objective was to find out answers to the following questions:

a) What was the impact of the Internet Pilot's License course on its participants?

b) What factors facilitate or inhibit ICT Literacy?

c) What factors contribute to an effective ICT skills training programme?

d) What is the role of the public library in providing ICT Literacy training?

Anisur Rahman ${ }^{8}$ sketched the digital divide phenomenon of Bangladesh. In this study he examined the ICT infrastructure of Bangladesh, position of Bangladesh at global level in terms of ICT use. The study also discussed the role of libraries in bridging digital divide, and causes of digital divide in Bangladesh.

Numerous studies have been conducted. Features of very few of these studies have been sketched in short in the following table:

\begin{tabular}{|c|c|c|}
\hline $\begin{array}{l}\text { Researchers' } \\
\text { name/s with } \\
\text { study time }\end{array}$ & $\begin{array}{l}\text { Study type with } \\
\text { geographical areas } \\
\text { covered }\end{array}$ & Main focus/findings \\
\hline Bo Kinney $^{9}$ & $\begin{array}{l}\text { Statistical and } \\
\text { literature review } \\
\text { type research } \\
\text { article. The } \\
\text { statistics is based } \\
\text { on United States } \\
\text { Census dataset, } \\
2000 .\end{array}$ & $\begin{array}{l}\text { I. Impacts of public libraries' } \\
\text { Internet facilities both on } \\
\text { general public and the librarian. } \\
\text { II. Efforts taken by libraries to } \\
\text { bridge digital divide. } \\
\text { III. Analysis of digital divide } \\
\text { situation in terms of household } \\
\text { income, household in poverty, } \\
\text { non-white household and non- } \\
\text { English speaking household. } \\
\text { IV. Research finding denotes that } \\
\text { digital gap has been created not } \\
\text { for income disparities but for } \\
\text { language and race. }\end{array}$ \\
\hline $\begin{array}{l}\text { Seyed Vahid } \\
\text { Aqili }^{10} \text { and } \\
\text { Alireza } \\
\text { Isfandyari } \\
\text { Moghaddam }\end{array}$ & $\begin{array}{l}\text { Literature review } \\
\text { based theoretical } \\
\text { survey in Pakistan. }\end{array}$ & $\begin{array}{l}\text { I. Clarification of Digital Divide } \\
\text { II. Description of major factors } \\
\text { that affect Digital Divide } \\
\text { III. Statement of the role of } \\
\text { librarians and information } \\
\text { professionals in bridging digital } \\
\text { divide }\end{array}$ \\
\hline
\end{tabular}




\begin{tabular}{|c|c|c|}
\hline $\begin{array}{l}\text { Songphan } \\
\text { Choemprayong }^{11}\end{array}$ & $\begin{array}{l}\text { Critical discussion of } \\
\text { US anticipation on } \\
\text { multilayer digital } \\
\text { divide and effects of } \\
\text { national } \\
\text { information policies } \\
\text { to bridge the digital } \\
\text { gap. }\end{array}$ & $\begin{array}{l}\text { I. Scope of digital divide. } \\
\text { II. Definition of stake holders who } \\
\text { can contribute to broadening or } \\
\text { narrowing digital divide. } \\
\text { III. Digital divide in USA. } \\
\text { IV. USA policies based on ICT } \\
\text { infrastructure development, } \\
\text { promoting digital literacy and } \\
\text { building digital society. } \\
\text { V. Recommendations for } \\
\text { improvement. }\end{array}$ \\
\hline $\begin{array}{l}\text { Zaitun, A. B } \\
\text { and Barbara } \\
\text { Crump }\end{array}$ & $\begin{array}{l}\text { A proposal to bridge } \\
\text { digital divides in } \\
\text { Malaysia. Role of } \\
\text { higher educational } \\
\text { institutions have } \\
\text { been stated here. }\end{array}$ & $\begin{array}{l}\text { I. Activities in effect to bridge } \\
\text { digital divide in Malaysia } \\
\text { II. Tracing out possibilities by } \\
\text { which higher educational } \\
\text { institutions can contribute to } \\
\text { bridge the digital gap. } \\
\text { III. Industries' role relating to } \\
\text { power generation, increasing } \\
\text { telephone line and its quality, } \\
\text { etc. } \\
\text { IV. Government's policies that have } \\
\text { been taken for ICT } \\
\text { development. }\end{array}$ \\
\hline $\begin{array}{l}\text { Tammi Moe } \\
(2004)^{13}\end{array}$ & $\begin{array}{l}\text { Survey article to } \\
\text { assess the impact of } \\
\text { public libraries on } \\
\text { bridging digital } \\
\text { divide in Colorado, } \\
\text { USA. }\end{array}$ & $\begin{array}{l}\text { Impact of Internet facilities on } \\
\text { different issues over the users of } \\
\text { public libraries were examined } \\
\text { under different demographic factors } \\
\text { such as age, race, education level, } \\
\text { etc. }\end{array}$ \\
\hline
\end{tabular}

\section{ICT STATUS AND DIGITAL DIVIDE IN BANGLADESH}

ICT status of Bangladesh is inadequate. Though the first Mainframe computer came to Bangladesh in 1964, the use of PC became popular very late to the common people. The Internet came late in Bangladesh, with UUCP e-mail beginning in 1993 and IP connectivity in $1996 .{ }^{14}$ Bangladesh got SEA-ME-WE-4 submarine cable connectivity on 21 May 2006. Currently there are 205 ISP; of these almost $80 \%$ ISPs are located in Dhaka. Including the government own BTCL a huge number of private organizations, i.e. mobile phone operators, private entrepreneurs and local broad band service providers are involved in the spread of internet service throughout the country. Initially the internet services were limited to Dhaka city. However with the initiative of government own BTCL, it expanded to all district towns of Bangladesh though the cost of internet is still high in most district towns due to limited users. Bangladesh saw an internet revolution when Citycell, a privately owned mobile company started to offer City Cell Zoom- an internet package for the mobile users and for all having modem to use City Cell sim card. Now almost all mobile operators offer mobile internet service for their respective users. According to the Internet World Stats $^{15}$ as of August, 2010 there are currently 995,560 internet users in Bangladesh and the internet penetration is $0.6 \%$.

Recently Bangladesh government has adopted a national ICT Policy-2009 which includes action items for realizing the goals of national development. Earlier national ICT Policy was published in 2002 aiming at building an ICT driven knowledge based society by the year 2010. National ICT Policy-2009 consists of 10 broad objectives, 56 strategic themes and 306 action items

Bangladesh has seen a telecom revolution recently. The following figure table shows the existing mobile operators and mobile users in Bangladesh.

Table 2: Mobile operators and subscribers in Bangladesh

\begin{tabular}{|l|c|c|c|}
\hline \multicolumn{1}{|c|}{ Operators } & \multicolumn{3}{c|}{ Active Subscribers } \\
\hline & Nov. 2010 & Nov. 2009 & Nov. 2008 \\
\hline Grameen Phone Ltd. (GP) & 28.843 & 22.75 & 20.83 \\
\hline $\begin{array}{l}\text { Orascom Telecom Bangladesh } \\
\text { Limited (Banglalink) }\end{array}$ & 18.843 & 12.99 & 10.21 \\
\hline Axiata Bangladesh Limited (Robi) & 12.059 & 8.87 & 7.90 \\
\hline Airtel Bangladesh Limited (Airtel) & 3.797 & 2.92 & 2.31 \\
\hline $\begin{array}{l}\text { Pacific Bangladesh Telecom } \\
\text { Limited (Citycell) }\end{array}$ & 1.873 & 1.97 & 1.79 \\
\hline $\begin{array}{l}\text { Teletalk Bangladesh Ltd. } \\
\text { (Teletalk) }\end{array}$ & 1.204 & 1.06 & 0.92 \\
\hline \multicolumn{1}{|c|}{ Total } & 66.621 & 50.55 & 43.96 \\
\hline
\end{tabular}

Source: Compiled from websites of Bangladesh Telecommunication Regulatory Commission (2010),

http://www.btrc.gov.bd/newsandevents/mobile_phone_subscribers.php

* Subscribers in Millions

**The above subscribers' numbers are declared by the mobile operators 
The above table shows very positive image of mobile use of Bangladesh. Above 66 million people in Bangladesh are currently using mobile telephones. Use of mobile telephones is increasing as mobile operators are offering affordable mobile packages. Now even poor people with very limited income can afford mobile phone for their personal use. Competitions are seen in the mobile business field as all mobile operators are trying to attract the people to use their mobile package.

Figure 1: Active subscribers and mobile operators in Bangladesh in 2010, 2009 and 2008.

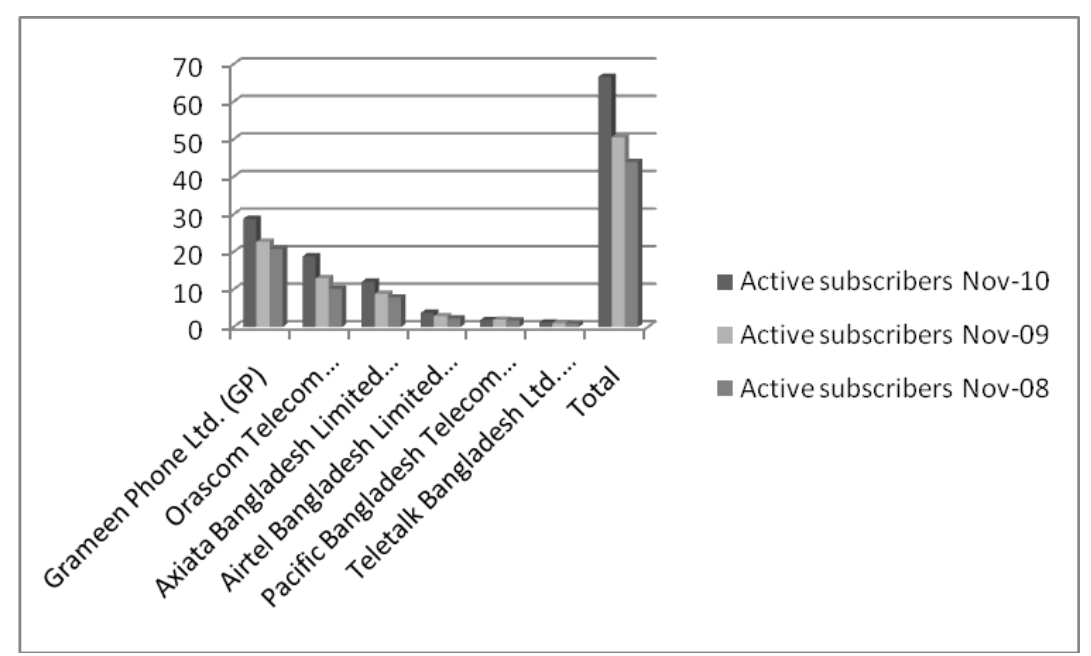

It is evident from the above figure that numbers of mobile phone subscribers are increasing day by day. One positive aspect is that all the mobile operators are getting benefit of increasing number of subscribers. This picture shows that investment in telecommunication sector in Bangladesh is beneficial.
Figure 2: Mobile penetration rate of Bangladesh and Asia

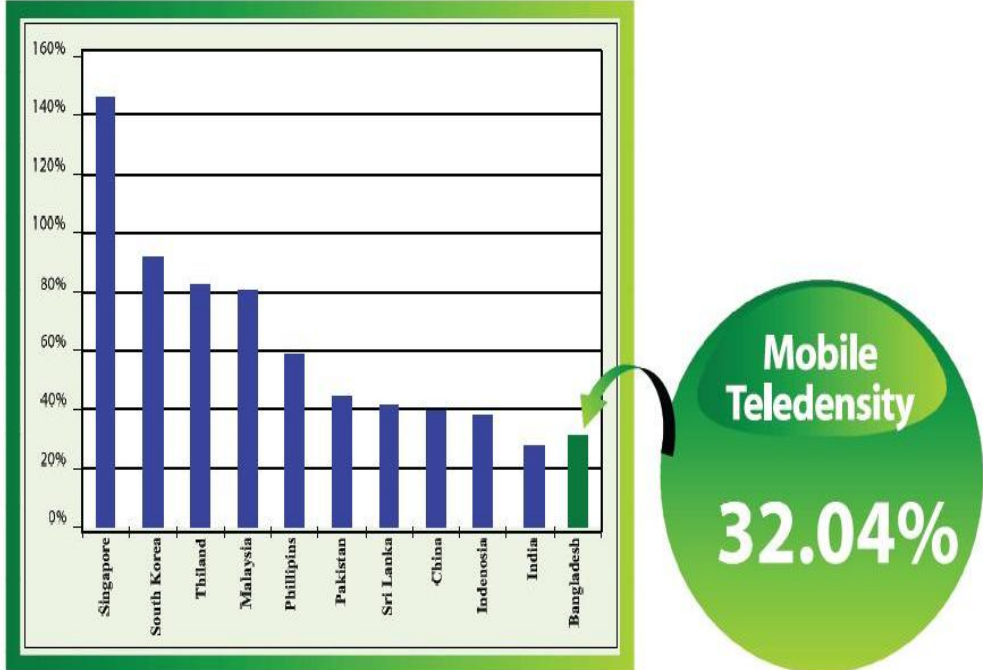

Source: Bangladesh Telecommunication Regulatory Commission Annual Report 2007-2008, p. 21, http://www.btrc.gov.bd/btrc/annual_report_07_08_english.pdf.

This figure also shows positive picture of mobile teledensity in Bangladesh. Bangladesh has more teledensity than India which is very positive indication for mobile usage in Bangladesh.

All these above indicators show positive telecommunication scenario in Bangladesh. Now time has come to see the overall ICT usage scenario in Bangladesh.

In the ITU, ${ }^{16}$ Information Society Statistical profiles 2009 Asia and the Pacific, IDI use sub-index Bangladesh ranked $27^{\text {th }}$ out of 27 countries in terms of use of ICT and rank and status remained the same from 2002 to 2007. This analysis indicates the inadequate use of ICT in Bangladesh.

Very frustrating picture reveals when we see rural and urban usage of ICTs. Table 3 speaks of the real situation. 
Table 3: Access to ICTs in Bangladesh in 2000 and 2005

\begin{tabular}{|l|c|c|c|c|c|c|}
\hline \multirow{2}{*}{ Residence } & \multicolumn{6}{|c|}{ Access to } \\
\cline { 2 - 7 } & Electricity & Telephone & $\begin{array}{c}\text { Mobile } \\
\text { Phone }\end{array}$ & Electricity & $\begin{array}{c}\text { Telephon } \\
\text { e }\end{array}$ & $\begin{array}{c}\text { Mobile } \\
\text { Phone }\end{array}$ \\
\hline National & 44.23 & 2.87 & 11.29 & 31.2 & - & - \\
\hline Rural & 31.19 & 0.33 & 6.05 & 18.7 & - & - \\
\hline Urban & 82.61 & 10.36 & 26.73 & 80.4 & - & - \\
\hline
\end{tabular}

Source: Bangladesh Bureau of Statistics (BBS), Household Income Expenditure Survey (HIES), 2005 (provisional)

Table 3 shows limpid digital divide between the residence of rural and urban areas in Bangladesh. At the national level only 44.23 percent has electricity access. In Rural areas it is $31.19 \%$ and in Urban areas it is $82.61 \%$. Where there is no electricity, we cannot think of use of the ICT equipment like computers, audio-visual materials and so on.

More frustrating picture comes in the following table:

\begin{tabular}{|l|c|c|}
\hline \multicolumn{2}{c}{ Table 4: Access to computer and e-mail } \\
\hline \multirow{2}{*}{ Residence } & \multicolumn{2}{|c|}{ \% of household have reported access } \\
\cline { 2 - 3 } & Computer & e-mail \\
\hline National & 1.36 & 0.20 \\
\hline Rural & 0.17 & - \\
\hline Urban & 4.88 & 0.81 \\
\hline
\end{tabular}

Source: Bangladesh Bureau of Statistics (BBS), Household Income Expenditure Survey (HIES), 2005 (provisional)

Table 4 clearly depicts disappointing picture of computer and e-mail use in Bangladesh. Substantial changes occurred during the last five years in terms of usages of computers and internet. However, still very few people use internet in Bangladesh. Especially people living in rural areas use internet very rarely. Though nowadays due to government and nongovernment initiatives to promote access to information, a good number of people are connected somehow with the internet system. Notable programme in this regards include Grameen Phone Community
Information Centre (CIC), Union Information Centre (UIC) of Bangladesh Government. Even though a large number of people are ICT illiterate and even they are educationally illiterate, they use internet with the help of others.

In Bangladesh digital divide exists between:

Urban and Rural Population: It is clear from the statistics presented at Table 3 and 4 . A distinct gap exists between the urban and rural population in terms of ICT usage.

Rich and Poor: Since rich people can have access to up-to-date ICT facilities, digital divide always exists between rich and poor. Poor people cannot afford high cost of modern ICT equipment. While Bangladesh has made significant inroads to poverty alleviation, the overall incidence of poverty remains unacceptably high with nearly 50 percent of the population below the poverty level. Although the headcount rate has declined, the actual number i.e. around 63 million people has remained roughly the same during the nineties. The number of people in extreme poverty declined modestly from 45 million to 42 million over the same period. Even the rich poor gap is alarmingly increasing day by day. The latest statistics, for example, reveals that the per capita income of the richest 5 per cent of the population was 18 times the per capita income of the poorest was 5 per cent in 1991-92, which has risen to 84 times by 2005. ${ }^{17}$ The statistics, however, portraits that the poor are becoming poorer, while the rich are getting richer. The rich-poor gap is gradually increasing.

Genders: Female members of the society are always getting less facilities and opportunities than the male members of the society. As Bangladesh is a conservative country, parents use to make hindrance for the female education and other facilities. Priority is always given to male members.

Government and Private Organizations: Digital divide exists largely between government and private organizations. Private companies and organizations are always ahead of exploiting latest technologies, whereas due to administrative complexities and lack of proper planning government organizations are lagging behind in technological development. For example, leading private university libraries in Bangladesh are doing practically good in offering ICT based library services. On the other hand leading public university libraries, e.g. University of Dhaka library is still far from ICT based modern library services. 
Dhaka City and Others District of Bangladesh: It is also transparent from the statistics presented by the Bangladesh Bureau of Statistics that digital divide exists between Dhaka City and other districts of Bangladesh. Naturally as Dhaka city is the capital city of Bangladesh, it enjoys better infrastructure than other districts of the city. As already mentioned, 80 percent of ISP is based in Dhaka city. Moreover, a large number of cyber centres are found in the Dhaka city, whereas the number of cyber cafés are very few in other district towns of Bangladesh.

Organization in Dhaka and Other Districts of Bangladesh: Naturally, organizations of Dhaka enjoy more infrastructural facilities than the organizations in other districts of Bangladesh.

Mainstream and the Tribal Population: Mainstream always receives more facilities than the tribal population. Tribal populations are always deprived of different opportunities and facilities.

Age: Usually aged people in Bangladesh especially people over 40 are reluctant to use modern technologies for their day to day activities. Therefore, digital divide exists between young generations and aged people in Bangladesh.

Disabilities: Disable people cannot access all the facilities offered by the government and other organizations. Especially in terms of use of ICT equipment very few organizations offer ICT equipment for disable people. Also government has very few initiatives for the disable people. Therefore digital divide always exits between disables and normal people.

Education: Clear digital divide exists between literate and illiterate population. Illiterate population usually do not use ICTs and they actually cannot use ICT equipment due to their ignorance. In Bangladesh poor population are mostly illiterate. As they are poor they cannot think of buying expensive ICT equipment or spend money for this service. However, poor illiterate population nowadays extensively use mobile phone as mobile phone in Bangladesh is very cheap as compared to other ICT equipment.

\section{INITIATIVES TO BRIDGE DIGITAL GAP}

The disparity in access to ICTs is a burning issue now which has noticed the attention of institutions like Digital Opportunity Task Force of the G8 countries, the World Summit on Information Society (WSIS), and so on. By their continuous campaign developed countries, UN agencies and donor agencies have come forward to uplift the poor ICT infrastructure and human capacity of less developed countries. Such initiatives are visible in Bangladesh. At the commencement of $21^{\text {st }}$ century, Bangladesh government being a member of different global associations starts taking pragmatic initiatives to enhance affordable ICT development. Bangladesh government has taken a policy to launch collaborative programmes with donor agencies as development partners as well as stakeholders and NGOs in the country to alleviate the digital divide situation here. Some of these programmes are:

\section{Bangladesh-Korea}

South Korea has been extending support toward the socio-economic development of Bangladesh since the establishment of diplomatic ties in 1973. Bangladesh accepted a grant assistance of $\$ 36$ million for the time span of 1991-2009 from South Korea through KOICA, a Korean aid agency and other Korean agencies. ${ }^{18}$ Of this grant assistance, a significant part was defined to create an ICT friendly working environment in different government offices, schools and universities, by building training centres, helping in the development of training curriculum, etc. Some of these leading initiatives by Korea in Bangladesh are:

\section{$>$ Bangladesh-Korea institute of ICT}

KOICA built this training facility in BCC's (Bangladesh Computer Council) head office in capital city Dhaka which started working in September 2005. The institute mainly arranges training sessions for government personnel with a view to develop their ICT skills that will ensure the government's initiative of e-government to a success. Up to December 2008, about 800 government officials and 35,000 general people have taken training in various ICT applications from this institution. ${ }^{19}$

\section{$>$ Bangladesh-Korea ICT training center for education}

In 2005 Bangladesh Bureau of Educational Information and Statistics (BANBEIS) and Korea International Cooperation Agency (KOICA) jointly initiated a project entitled 'Establishment of Bangladesh-Korea ICT Training Center for Education (BKITCE)'. The duration of the project was July 2006 to June 2009. The prime objective of this project was to build appropriate IT infrastructure by setting up and operating a state- 
of-the-art Training Centre in the country with 5 (five) ICT labs in BANBEIS Computer Division. Under the project ICT education and training was provided to the central and field level officials/staff as well as teachers at secondary and higher secondary levels. ${ }^{20}$

Bangladesh-Korea Information Access Centre (IAC)

Bangladesh-Korea Information Access Centre (IAC) at the Department of Computer Science and Engineering (CSE), BUET was inaugurated on December17, 2008. This is the first Information Access Centre established by Korean Agency for Digital Opportunity and Promotion (KADO) in Bangladesh with the aim of supporting ICT development here and promoting bilateral collaboration between the People's Republic of Bangladesh and the Republic of Korea under a Memorandum of Understanding (MOU) signed between BUET and KADO on October 20, 2008. Under this MOU, BUET has provided 3 rooms in which KADO has established the IAC comprising an IT training laboratory, a Seminar Room, and an internet lounge. KADO has performed the interior decoration of this centre and furnished and installed IT equipment. Along with conducting regular classes of the department, the facilities of the centre is used to grow IT awareness of people by offering various IT programmes on non-profit basis. ${ }^{21}$

\section{$>$ Korea aided project for e-file management systems}

The Establishment Ministry of Bangladesh and KOICA signed an agreement for the implementation of an ICT project on 26 May, 2010. It is expected that during the two years of this project, an e-file management system will be implemented for the ministry. KOICA will provide e-file management system software and all other necessary IT accessories along with interior renovation for the ICT training room at the Public Administration Computer Centre of the concerned ministry. ${ }^{22}$

\section{$>$ Bangladesh Open University (BOU) project}

KOICA is intending to assist Bangladesh Open University to launch a very efficient Learning Management System (LMS) and ICT based Web Integrated ODL university management system to envisage the enhancement of distance education to reach the remote areas of the country through launching ICT based educational tools. ${ }^{23}$

\section{> Finance Ministry and KOICA project}

Ministry of Finance, Bangladesh took financial and technical support from KOICA to implement the project entitled 'Strengthening ICT Training and System of Bangladesh Bureau of Statistics (BBS)'. The project duration covered two fiscal years of 2008 and 2009. The main objectives of the project were to upgrade the statistics production and analytical capacity of the BBS with the introduction of a modern database system and improve the statistical processing ability of BBS officials through advanced training. ${ }^{24}$

\begin{tabular}{|c|c|}
\hline $\begin{array}{c}\text { Case Study 1: Grameen Bank } \\
\text { Village Phone }\end{array}$ & $\begin{array}{l}\text { Case Study 2: Bangladesh } \\
\text { Telecentre Network }\end{array}$ \\
\hline $\begin{array}{l}\text { Grameen Bank gave birth to the } \\
\text { micro-credit movement in } 1976 \\
\text { by giving the poorest of the poor } \\
\text { access to small loans without the } \\
\text { requirement of collateral. By } \\
\text { bringing electronic connectivity } \\
\text { to rural Bangladesh, Village } \\
\text { Phone is bringing the digital } \\
\text { revolution to the doorsteps of } \\
\text { the rural poor and unconnected. } \\
\text { By being able to connect to urban } \\
\text { areas or even to foreign } \\
\text { countries, a whole new world of } \\
\text { opportunities is opening up for } \\
\text { the villagers in Bangladesh. Thus, } \\
\text { the telephone becomes a } \\
\text { weapon against poverty. }{ }^{25} \text { By the } \\
\text { end of } 2008, \text { there were about } \\
\text { three hundred fifty-four } \\
\text { thousand village phone ladies } \\
\text { who have together taken loans } \\
\text { amounting to BDT } 2.57 \text { billion. }{ }^{26}\end{array}$ & $\begin{array}{l}\text { Bangladesh Telecentre Network } \\
\text { (BTN) is a coalition of } \\
\text { organisations for fostering } \\
\text { telecentre movement in } \\
\text { Bangladesh. It is an inclusive } \\
\text { network, where any individual or } \\
\text { an institution committed to bring } \\
\text { ICT to the doors of the common } \\
\text { people across the country can be } \\
\text { a member or partner. The } \\
\text { network is based on the idea of } \\
\text { maximizing the advantages of } \\
\text { information and communication } \\
\text { technologies (ICTs) through } \\
\text { sharing of experiences and } \\
\text { knowledge within the } \\
\text { components of the organisation. } \\
\text { It envisages addressing poverty } \\
\text { alleviation through accessing } \\
\text { information and knowledge by } \\
\text { the poor as an overarching } \\
\text { dimension of the Network's } \\
\text { mission. As of January, } 2010 \text { there } \\
\text { are } 2165 \text { telecentre in } \\
\text { Bangladesh. }{ }^{27} \text {. }\end{array}$ \\
\hline
\end{tabular}




\section{Bangladesh-Microsoft}

During Bill Gate's visit to Bangladesh in 2005, Microsoft signed a memorandum of understanding with the Ministry of Education, Bangladesh to train over 10,000 teachers and over 200,000 students at primary and secondary levels. It was an effort by the Partners in Learning Grant programme, a component of Microsoft's Partners in Learning Initiative programme worldwide. The programme was intended to be implemented through the following three years. In addition to this, alliances were also established and agreements were made with 10 of the leading universities in Bangladesh to ensure easier access and exposure to the latest software and technology at affordable prices for teacher and students. $^{28}$

\section{Bangladesh-Intel}

Intel Corporation made an attempt to help bridge the digital divide in Bangladesh through its Intel World Ahead Programme. In this regard, in 2008, Intel Corporation signed some Memorandum of Understandings (MoU) and conducted discussions with ministry of education and other agencies to:

- $\quad$ supply 1,000 personal computers to schools in 64 districts of Bangladesh with a view to introduce information technology based education system in the country

- $\quad$ ensure cost effective Internet connectivity at these schools

- $\quad$ help setting up targeted 40,000 Telecenters across the country by 2011, in collaboration with Grameen Solution and Bangladesh Telecenter Network, to work as a service delivery platform for farmers, workers, students and all kinds of people.

- $\quad$ provide cost effective computers to rural students

Though Bangladesh government already have such kind of collaboration with many other donor agencies, Intel urged to build a long term planning for ICT development in Bangladesh. ${ }^{29}$

\section{Bangladesh-UNDP}

In order to provide service at doorsteps through ICTs for its citizens, Bangladesh government has taken a massive development programme called Access to Information $(\mathrm{A} 2 \mathrm{i})^{30}$ with technical and a major financial assistance from UNDP, Bangladesh. A2i programme started its journey in 2006. Expected outputs of $A 2 i$ are:

$>$ Enhanced e-service for citizens

$>$ Quality of public servants enhanced

$>$ E-Governance quick-win initiatives enhanced

> Multi sector e-Governance initiatives formulated

Achievements of $\mathrm{A} 2 \mathrm{i}$ regarding ICT infrastructure and human capacity building along with increasing access to digital technologies are:

$\checkmark$ Development of district web portals for 64 districts of Bangladesh in order to provide necessary information to rural people. For further enrichment of these portals, such as making citizen compatible web content and communication tools with a view to close the gap between government and people, a competitive phenomenon has been created among ministers of respective districts with the holding of "Digital Innovation Fair". By these fairs newly invented digital facilities are brought to the sight of local people.

$\checkmark$ Implementation of Union Information Centre (UIC). It is a joint venture of $\mathrm{A} 2 \mathrm{i}$ and Local Government Division of LGRD Ministry. Already 1000 UICs have been established and there is an aim to set up a UIC at every union of Bangladesh by 2011. The UICs will be set up at Union Council Complexes of respective unions. Services of these centres, at a lower cost, will include:

- Internet connection to facilitate access to world's knowledge repository.

- Offline collections of videos, audios, animations, information on agriculture, health, education in text format.

- Training facilities on computer and related courses.

- Computer aided commercial services such as composing, printing, scanning, photography, etc. ${ }^{31}$

$\checkmark \quad \mathrm{A} 2 \mathrm{i}$ has made significant contribution to the following policy reforms:

- finalization of the Telecom Policy 2010 and Rural Connectivity Policy 2010.

- facilitating National e-Governance Architecture group and Cyber Security Committee. 
- intervention to such polices as Right to information and National ICT policy.

- ICT in Education Master Plan.

- Significant modification has been brought on the draft policy of Public Private Partnership (PPP). The concept of PPP is a new inclusion to the budget of Bangladesh government in the fiscal, July 2010-June 2011.

$\checkmark$ Inauguration of digital purjee management system in 15 sugar mills of Bangladesh by Prime Minister on 12 December, 2010. It is the aftermath of the pilot project of e-purjee at Faridpur and Mobarakganj Sugar Mills conducted by Access to Information (A2i) programme at the Prime Minister's Office along with and funded by Bangladesh Sugar and Food Industries Corporation (BSFIC) under the Ministry of Industries and UNDP, Bangladesh. Purjee is the permission letter from a farmer for the purchase of his produced sugarcane by a sugar mill.

$\checkmark$ Development of online General Diary (GD) filing system at 41 police stations of Dhaka Metropolitan Police.

Some other initiatives of the A2i programme planning to implement in near future are:

> $\mathrm{A} 2 \mathrm{i}$ has been involved with the work of Domestic Network Coordination Committee (DNCC). Domestic network coordination committee was set up with the goal of better coordination between different agencies and ministries so that the unused infrastructure, such as laid out fiber optic cable, could be used for connectivity in the rural areas down to union level.

$>$ An Online Library Management System is under construction. This is another quick win initiative by the National Public Library with technical assistance from A2i programme.

$>$ To enhance class room performance of secondary school teachers an initiative entitled "ICT-enabled Teacher Training Programme" is under processing. By this programme, digital contents for teacher training will be developed. A similar programme has been under processing for primary school teachers.

> A2i has a plan to establish one stop service in all District Commissioners' (DC) office of the country. The aim of this initiative is to provide service to the citizens at one visit.

\section{BRIDGING DIGITAL DIVIDE THROUGH PUBLIC, SCHOOL AND COLLEGE LIBRARIES}

Bridging digital divide at national level is not possible overnight. It requires dedicated, strong, goal oriented and long term government and nongovernment initiatives. Only government or only NGOs initiatives are not enough to reduce digital divide at the national level. Joint coordinated long term, sustainable programmes are very much required to effectively reduce digital divide.

This study is designed to show how public, school and college libraries can help lessening digital divide as we firmly believe that these libraries can play a very substantial role in reducing digital divide at the national level. Before we attempt to see how these libraries can reduce digital divide at the national level in Bangladesh, we should see the existing ICT status in these libraries in Bangladesh.

The library movement in Bangladesh started with the establishment of four public libraries in the district towns of Jessore, Bogura, Barisal and Rangpur in 1854. Government initiatives in setting up a countrywide public library system started with the establishment of Bangladesh Central Public Library in 1958. Currently in Bangladesh there are 68 government public libraries and 1603 non-government public libraries.

The 1980s are considered as the beginning of the automation era as far as libraries and information institutions in Bangladesh are concerned. The International Centre for Diarrhoeal Disease Research, Bangladesh (ICDDR,B) Library and Agricultural Information Centre (AIC) are pioneers in creating bibliographic databases on specialized fields using microcomputers. $^{32}$ The tremendous growth of Information and Communication Technology has opened the door for the libraries to make use of technological facilities for the betterment of user services. But, even today both government and non-government are unable to establish a fullfledged division of Information Technology. Nafiz Zaman ${ }^{33}$ reported that among 68 government public libraries only 14 public libraries have some kind of ICT facilities. He also reported that in 2004-2005 fiscal year a project was taken by the government of Bangladesh to set up cyber centre at the Bangladesh Central Public Library. More than 10 computers were purchased for this purpose. Unfortunately, the cyber centre has not been started yet. Recently BBC- UK based new agency offered some computers with internet connection for some selected public libraries in Bangladesh which are not enough for a huge public library users. It is a matter of regret 
that government of Bangladesh has failed to realize the importance of modernizing public library system with proper ICT facilities. So far no worth mentioning projects have been taken by any government of Bangladesh.

In Bangladesh non-government public libraries have no ICT facilities. ICT scenario in both government and non-government public libraries are thus frustrating. With these very limited ICT facilities public libraries cannot play any role in lessening digital divide in the country.

Very alarming situation exists in school and college libraries in Bangladesh. According to Bangladesh Bureau of Educational Information and Statistics $^{34}$, Dhaka, there are 82,218 Primary Schools, and 317 Secondary Schools. Sixteen hundred colleges affiliated with National University of Bangladesh have some kind of libraries. There are more than 1200 intermediate colleges which have small library with limited reading resources. ICT status in school and college libraries in Bangladesh is very much disappointing. Only a few school and college libraries in Dhaka have very limited computer facilities, especially those offering computer science course as part of secondary and higher secondary levels. As part of this study we contacted several college and school librarians regarding ICT status in their libraries. What the librarians shared is really upsetting. We contacted about 55 school and college librarians and found none of the libraries have computer facilities. We found, among 55 schools and college libraries, only 2 private college libraries that have Computer Lab facilities in the college, however no computer has been given to the libraries.

A comprehensive national plan to reduce digital divide through public, school and college libraries should be formulated by the government of Bangladesh to reduce digital divide at the national level. This plan should ensure special priority and concentration to the development of public, school and college libraries in Bangladesh. As public library is a place for mass public interactions and exchanges of ideas, proper concentration should immediately be given to nationwide public library development. New public libraries should be established in villages and non-government public library should be financially supported. The number of villages in Bangladesh quoted in the 1991 census is 68,038 with a national average of 232 households per village. ${ }^{35}$ Each and every village should have one small range public library with internet and other communication facilities. This public library will act not only as just a place for reading but will be a place for public interactions. This public library will be setup in a way that would work as One Stop Information Centre. All kinds of information will be provided to the villagers, e.g. if anyone wants to know about university admission test, share business update, government policies and initiatives, scholarships available, health information and other information required for day-to-day use, s/he will be able to ask public library staff for his/her information needs and will be able to consult the online and printed information resources.

Government should ensure ICT facilities to each school and college libraries in Bangladesh to produce qualified, ICT skilled future generations. Unless government ensures ICT facilities for the school and college students, we cannot think of qualified future generations.

It is not possible to establish over 68 thousand public libraries and to ensure ICT facilities to all schools and colleges overnight. However, it is possible to create a road map and then proceed according to that road map. Current government of Bangladesh pledged to convert Bangladesh into 'Digital Bangladesh' by 2021 which is the golden jubilee year of Bangladesh independence. Several projects and programmes have been initiated by the government of Bangladesh and other organizations to support government's vision of Digital Bangladesh. Unfortunately, no worth mentioning projects and programmes to convert traditional libraries into digital libraries have been taken so far. Government of Bangladesh still unable to realize the fact that without converting conventional libraries into digital one and ensuring right to information to all , Bangladesh will never be able to see a complete digital revolution and will never be able to convert its traditional societies into information society.

Government must propose the multinational companies and donor agencies to help develop the public libraries of every village of Bangladesh, to offer ICT equipment to all school and college libraries. Business organizations can help building public libraries and providing ICT equipment to school and college libraries as part of 'Corporate Social Responsibility'.

Public libraries in villages should be controlled by the district public libraries concerned. District libraries will be controlled by Divisional libraries and divisional libraries will be controlled by the Central Public Library. As it is not possible for Central Public Library to control village libraries, responsibilities should be decentralized to divisional and district libraries. Public libraries in villages will work as a panacea for village development. It should offer informal education programme for the illiterate aged people and even for the illiterate working people. It should 
arrange ICT training programme for the villagers especially for the young generations. Preferences should always be given to the young members of the society as they are the future of the nation. Unless we ensure proper education and ICT facilities we will not be able to produce educationally qualified and technologically skilled future generations. Public libraries in villages will work to promote education, health, socio-economic status of the villages. Different awareness and training programmes will be organized by the village public libraries with a view to active public participations and interactions. As we propose not only conventional public library but also One Stop Information Centre, we hope public library will comprise the following core sections at least to ensure mass participation-

Figure 3: Major sections of Public Libraries as One Stop Information Centre

\begin{tabular}{|l|l|}
\hline General Reading Room Section \\
\hline Cyber Centre \\
\hline Agriculture Informaion and Support Section \\
\hline Education, Health, Government Information Section \\
\hline Cultural Centre \\
\hline Children's Corner with ICT facilities \\
\hline Others (if necessary) \\
\hline
\end{tabular}

ICT development in school, college and public libraries should be done phase by phase. It should be a 10 years project. During the first five years all divisional and district public libraries and all schools and college libraries will be given computers with internet connections. Next five years will be spent on establishing and developing public libraries in villages offering computers with internet connection will be given to rest of the school and college libraries lacking ICT access.

Figure 4: Phase by phase development to reduce digital divide through public, school and college libraries

1st Phase
- Computers with
internet connection for
all divisional and
district public libraries.
- Computers with
internet connections
for school and college
libraries nationwide.

2nd Phase
- Establishing public
libraries in villages.
- Computers with
internet connection for
school and college
libraries lacking ICT
access.

If the government immediately takes necessary initiative to ensure ICT facilities to all schools, college and public libraries, by 2021 government will be able to considerably change the current digital divide scenario. Concentration from the concerned ministry of the government parts should be given to library sectors. It is a matter of great regret that library field has been facing negligence from the very beginning of library movement in Bangladesh. Unless Government realize the importance of libraries in building qualified, talented future generation, government will never be able to help produce a meritorious generation. Time is running out to think about libraries and offer highest priority to library based education system. Government and other development organizations should come forward to help reduce digital divide through libraries.

\section{CONCLUSION}

It is not possible for any government to give one computer with internet connection to each family living Bangladesh to make competent in ICT. 
However, it is possible to establish and develop public libraries in the villages with the ICT facilities and to upgrade school and college libraries with modern facilities to change the existing vulnerable ICT environment across the country and reduce digital divide extensively. One thing we must keep in mind that just offering computer will never help building 'Digital Bangladesh' and produce competent future generation. We have to think of proper utilization of the technology and ensure necessary training for librarians, teachers, students and other population.

ICT training should be given to all school and college students not just only those taking computer course as part of Secondary and Higher Secondary examinations. ICT is a must for all from school to university level. Therefore ICT courses should be made compulsory for them. Those who are not students must be benefited from the training courses of public libraries. Public libraries should work as a platform for reducing illiteracy and should offer time to time training on various matters to the readers in particular and citizens in general.

Launching an all-out severe movement from the library associations to promote libraries at the national level has become essential at this moment. Library Association of Bangladesh (LAB) and Bangladesh Association of Librarians, Information Scientists and Documentalists (BALID) and other professional bodies should convince government and other donor agencies for funding development projects in the field of library and information science and computer technology.

As part of this study we have found acute digital divide at the national level. To reduce digital divide and to produce qualified future generations there is no alternative to library based education and training. Coordinated long term projects should be taken immediately by the government of Bangladesh. Donor agencies, multinational business organizations and development organizations should help government implement these projects effectively. There is a trend in Bangladesh that projects taken in one government's term is usually ignored by the other government. This is a very bad practice. All the political parties should work together forgetting their political bias in building qualified, prosperous, peaceful nation by the next one decade.

\section{REFERENCES}

1. Sawyer, Stacey C., Williams, Brian K. and Hutchinson, Sarah E. Using information technology: a practical introduction to computers and communications. $5^{\text {th }}$ ed. Boston: McGraw-Hill, 2000.

2. UNESCO. Draft recommendation on the promotion and use of multilingualism and universal access to cyberspace and report by the director-general. UNESCO General Conference, $31^{\text {st }}$ Session, Paris, 2001. (Retrieved on Nov. 25, 2010 from

http://www.nethics.net/nethics neu/n3/quellen/informationspolitik/ UNESCO recommendation-cyberspace 27-07-01.pdf)

3. Norris, Pippa. Digital divide: civic engagement, information poverty, and the internet worldwide. New York: Cambridge University Press, 2001.

4. Mutual, Stephen M. Deploying development informatics in bridging the digital divide: challenges \& opportunities. Keynote paper presented at the $11^{\text {th }}$ DIS annual conference. 2nd - 3rd September, Richards Bay, University of Zululand, South Africa, 2010. (Retrieved from

http://www.lis.uzulu.ac.za/research/conferences/2010/DIS\%20confer enceFP\%20Mutula\%20Sept\%20\%2025\%20final.pdf)

5. Kainth, Gursharan Singh. Bridging rural digital divide: Status and future agenda. Amazines: Free Article Archive, 2007. (Retrieve on Nov. 19, 2010

from

http://www.amazines.com/Current Affairs/article detail.cfm?articlei $\mathrm{d}=392201)$

6. Singh, Neena. Bridging the digital divide in India: some challenges and opportunities. World Libraries.v. 17(1), 2007. (Retrieved on Nov. 30, 2010 from http://www.worlib.org/)

7. Oliver, E. Lynn, ed. Public libraries and ICT literacy: bridging the digital divide, 2007. (Retrieved on Nov.11, 2010 from

http://www.lib.sk.ca/Public-Libraries-ICT-Literacy)

8. Anisur Rahman, Md. Access to global information - a case of digital divide in Bangladesh, 2007. (Retrieved on Nov. 1, 2010 from http://digaria.com/postings/fa7781771b1594ed71d7763640abe6fd)

9. Kinney, Bo. The internet, public libraries, and the digital divide. Public Library Quarterly, v. 29(2): $104-161,2010$. DOI:10.1080/01616841003779718 
10. Aqili, Seyed Vahid and Moghaddam, Alireza Isfandyari. Bridging the digital divide: the role of librarians and information professionals in the third millennium. The Electronic Library, v. 26(2): 226 - 237, 2008. DOI: $10.1108 / 02640470810864118$

11. Choemprayong, Songphan. Closing digital divides: The United States' policies. Libri v. 56: 201-212, 2006. (Retrieved on Nov. 19, 2010 from http://www.librijournal.org/pdf/2006-4pp201-212.pdf)

12. Zaitun, A. B. and Crump, Barbara. Overcoming the digital divide - a proposal on how institutions of higher education can play a role. Malaysian Online Journal of Instructional Technology, vol. 2(1), 2005. (Retrieved on Dec. 10, 2010 from http://pppij.usm.my/mojit/)

13. Moe, Tammi. Bridging the digital divide" in Colorado libraries: Survey results from the Colorado public libraries \& the digital divide"2002 study. Public Libraries, Jul.-Aug., 2004. (Retrieved on Nov. 19, 2010 from http://www.Irs.org/documents/DD_2002/moefeature.pdf.)

14. Shuva, Nafiz Zaman. Integrating ICT into university curriculum: a proposal for the faculty of arts, university of Dhaka, Bangladesh. Proceedings of Informing Science \& IT Education Conference (InSITE): 487-502, 2010. (Retrieved on Nov. 19, 2010 from http://proceedings.informingscience.org/InSITE2010/InSITE10p487502Shuva843.pdf)

15. Internet world stats. Asia marketing research, internet usage, population statistics and facebook information, 2010. (Retrieved on Dec. 10, 2010 from http://www.internetworldstats.com/asia.htm)

16. International Telecommunication Union (ITU). Information society statistical profiles 2009 Asia and the Pacific, 2010. (Retrieved on Dec. 25, 2010 from

http://www.itu.int/ITU-D/ict/material/ISSP09-AP_final.pdf)

17. Ahmad, Q. K. Internal management key to economic health. The Daily Star. May 13, 2006. (Retrieved on Jan. 01, 2011 from http://www.thedailystar.net/2006/05/13/d6051301085.htm)

18. Trade, power, ICT to top agenda. The Daily Star. Aug. 16, 2010). (Retrieved on Nov. 19, 2010 from

http://www.thedailystar.net/newDesign/news-details.php? nid $=150935$

19. Barkatullah, Tarique Mosaddique. Country report, Bangladesh. UN: APCICT, 2008. (Retrieved on Nov 19, 2010 from http://www.unapcict.org/ecohub/resources/ict-human-capacitybuilding-in-bangladesh)

20. BANBEIS, Dhaka. Brochure, 2007. (Retrieved on Dec. 30, 2010 from http://www.banbeis.gov.bd/devnetsolutions/

BANBEIS_PDF/Pub.No.381\%20Bangladesh\%20korea\%20ICT\%20trainin g\%20center\%20for\%20education\%20\%28BKITCE\%29\%20Brochure\%20 \%286pages\%20folder\%20\%29september\%202007.pdf)

21. Bangladesh-Korea Information Access Center (IAC) information revisited. Bangladesh University of Engineering and technology (BUET). (Retrieved October 27,2010, from

http://www.buet.ac.bd/?page id=712)

22. South Korea to assist ICT development. The Daily Star. May 27, 2010. (Retrieved on Nov 30, 2010 from http://www.thedailystar.net/newDesign/newsdetails.php?nid=140196)

23. Korea to fund 2 projects worth $\$ 7 \mathrm{~m}$. The Independent. November 29 , 2010. (Retrieved on Dec. 20, 2010 from

http://www.theindependentbd.com/business/finance/ 21192-koreato-fund-2projects-worth7m.html)

24. KOICA, ERD sign 'record of discussions' to implement $\$ 1.58 \mathrm{~m}$ project. The Financial Express. Feb. 29, 2008. (Retrieved on Nov. 30, 2010 from http://www.thefinancialexpress-bd.com/more.php?news id $=26638 \&$ date $=2008-02-29$ )

25. South Asian success stories: Grameen village phone, village email and village internet Bangladesh. The South Asian. February, 2001. (Retrieved Nov.21, 2009 from

http://ijedict.dec.uwi.edu/viewarticle.php?id=487)

26. Grameen Phone Community Information Centre About GPCIC. 2009. (Retrieved on Jan. 09, 2010 from

http://www.gpcic.org/index.php?main=0\&page id=1\&location=About \%20Us)

27. Bangladesh Telecenter Network. About BTN. 2009. (Retrieved on Jan. 09, 2010 from http://www.mission2011.net.bd/ )

28. Hui, Florence. Bridging digital divide in Bangladesh by Microsoft. Digaria. Dec. 7, 2005. (Retrieved on from http://digaria.com/postings/fa7781771b1594ed71d7763640abe6fd) 
29. Intel to provide 1,000 PCs for schools. The Daily Star. Mar 23, 2008. (Retrieved on Nov. 30, 2010 from http://www.thedailystar.net/story.php?nid=28930)

30. Prime Minister's Office. Quarterly report of access to information (A2i) programme, Jan-Mar 2010. (Retrieved on Dec. 25, 2010 from http://a2i.pmo.gov.bd/index.php?option=com content\&task=blogcat egory\&id=3\&ltemid=189)

31. Hasib, Nurunnabi, Anis Rahman, and Rahitul Islam Ruel. Gram Banglake badle dibe Union Tathyaseba Kendra (in Bengali). The Monthly CNEWS, v. 8(9):23-28, 2010.

32. Khan, M.S.I. Developments in new information technologies and their applications and prospects in Bangladesh. Media Asia, v. 16(1): 32-40, 1989.

33. Shuva, Nafiz Zaman. Status of ICT in public libraries of Bangladesh. Asian Journal of Library and Information Science, V. 2(1): 1-15, 2010.

34. Bangladesh Bureau of Educational Information and Statistics. Primary, secondary and college education statistics. Dhaka: BANBEIS, 2008. (Retrieved on Dec. 10, 2010 from http://www.banbeis.gov.bd/)

35. Banglapedia. Village. Dhaka: Asiatic Society of Bangladesh, 2006. (Retrieved on Dec. 10, 2010 from

www.banglapedia.org/httpdocs/HT/V 0047.HTM) 